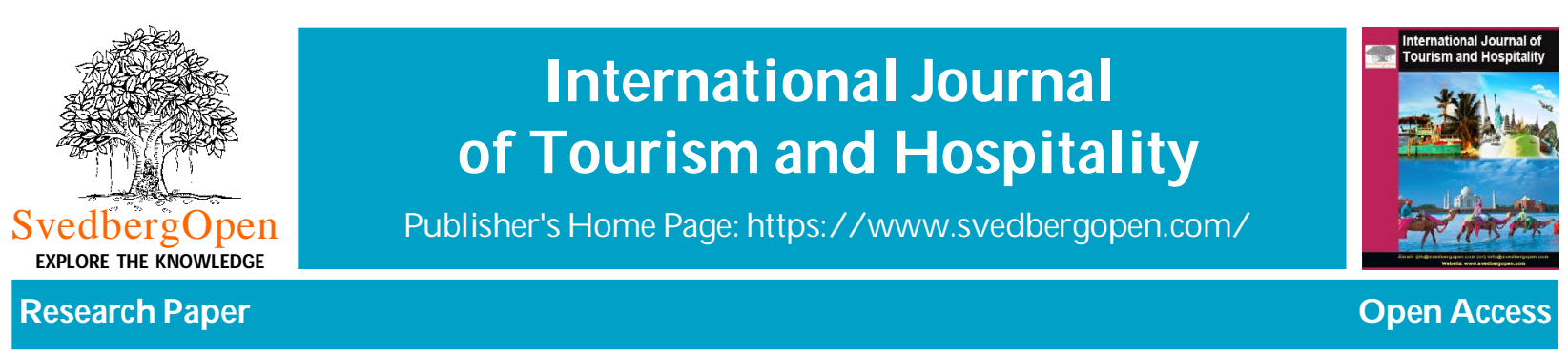

\title{
Individual and social marketing in cultural routes operation
}

\author{
Piskóti, István ${ }^{1}$ and Nagy, Katalin ${ }^{2 *}$ \\ ${ }^{1}$ Head of Marketing Institute, Department of Marketing Institute, University of Miskolc, Miskolc, 3515 Hungary. \\ E-mail: piskoti@uni-miskolc.hu \\ ${ }^{2}$ Master Lecturer, Tourism Department of Marketing Institute, University of Miskolc, Miskolc, 3515 Hungary. \\ E-mail: nagy.katalin@uni-miskolc.hu
}

Article Info

Volume 1, Issue 1, January 2021

Received : 15 November 2020

Accepted : 25 December 2020

Published : 04 January 2021

doi: 10.51483/IJTH.1.1.2021.14-24

\begin{abstract}
According to modern trends, tourism offer becomes more and more diversified. The most important feature of tourism products is complexity, and this, together with the experiencecentric demands, sets the tourism enterprises before new challenges, highlighting the necessity not only for product, but process and organizational innovations, too. The aim of our research is to study how different forms and models of cooperation, and the consequent joint marketing activities can effectively contribute to successful tourism innovations, product development and management, analyzing the examples of a specific field of tourism. Cultural routes have a special, determining role among tourism products. We have analyzed the possible problems and means of solutions arising from complexity-occurring in the course of development and realization-and also the criteria of marketability and competitiveness. Our starting hypothesis is that the more complex a tourism product is, the more broader and well-planned cooperation, that is the so-called stakeholder-management is necessary between the enterprises and community (non-profit) tourism organizations. We have carried out our research within and after a Hungarian-Slovakian project aiming to develop joint tourism packages along thematic routes. We have examined the co-operational abilities and intensity of the tourism actors in both countries. Solutions mixing business and social marketing techniques equally appeared in the development and management of cultural routes as complex tourism products, but, at the same time, they have not formed an efficient cooperational system. Our tested, competence-marketing based cooperational model, introduces the determining actors of heritage-based cultural routes, emphasizing the importance of the existence of an adequate coordinating-managing marketing organization. According to our results, the absence of such an organization hinders the successful operation of cultural routes, which was confirmed by the comparison of an effectual Swiss example and a similar Hungarian tourism product initiation.
\end{abstract}

Keywords: Cultural routes, Cooperation, Social marketing in tourism, Stakeholder management

(C) 2021 International Journal of Tourism and Hospitality. This is an open access article under the CC BY license (https://creativecommons.org/licenses/by/4.0/), which permits unrestricted use, distribution, and reproduction in any medium, provided you give appropriate credit to the original author(s) and the source, provide a link to the Creative Commons license, and indicate if changes were made.

\section{Introduction}

Tourism is one of the leading and most dynamic fields in global economy, even in spite of the protraction of the economical crisis. The number of international tourist arrivals grew by $4 \%$ in 2012 (compared to 2011), and reached the

\footnotetext{
* Corresponding author: Nagy, Katalin, Master Lecturer, Tourism Department of Marketing Institute, University of Miskolc,

Miskolc, 3515 Hungary.E-mail: nagy.katalin@uni-miskolc.hu
} 
magic 1 billion for the first time. A slower, about 3-4\% growth is forecasted for 2013, in line with the UNWTO's long-term outlook to 2030, which counts with an average growth of 3, 8\% per year between 2010 and 2020. Europe keeps its leading position, with a $3 \%$ growth, in spite of the economical pressure, and within the continent, the destinations of Central and Eastern Europe could reach the highest result with $8 \%$ growth (UNWTO, 2013). According to modern trends, tourism offer becomes more and more diversified, sometimes with quite surprising combinations by mixing elements from culture, history, industry or other economic fields. This is a natural consequence of the demand for innovations, being a determining factor in competitiveness, and also of other reasons: seeking novelty; tourism is really experiment-centric; and furthermore - partly also as a result of economical difficulties - the tendency of travels to be more in number but shorter in duration, consumers are more price-value conscious and quality became an important factor in decisions.

The most important feature of tourism products is complexity - that is they have to include all service elements to satisfy the more and more refined consumer needs (Lagrosen, 2005). The nature of tourism products is widely researched (Medlik and Middleton, 1973; Levitt, 1981; Smith, 1994; Middleton and Clarke, 2001; Gyöngyössy and Lissák, 2003; Lengyel, 2004; Michalkó, 2012), the characteristics of complexity and being experience-centric can be found in all models, emphasizing the inseparability, i.e., the necessity of consumer involvement. These represent a main line in our research of cultural routes.

There is a rich literature of heritage tourism, and the questions of heritage (Richards, 2003; Nuryanti, 1996; Hall and McArtur, 1998; Tunbridge and Ashworth, 1996; Swarbrook, 1994; Nurick, 2000; Silberberg, 1995; Fladmark, 1994; PuczkóRácz, 2000). According to Nuryanti (1996) heritage is part of the cultural traditions of a society, and also part of a community's identity. It is such a past value which is considered to be worthy to preserve and pass over to the next generation (Hall and McArthur, 1998). Tunbridge and Ashworth (1996) say that there are five main aspects in the broader sense of heritage: (1) any physical remains of the past, (2) individual and collective memories, intangible elements of the past, (3) results of cultural and artistic creativity, (4) natural environment, and (5) the so-called heritage industry, i.e., the different economic activities built on these.

According to Swarbrooke's (1994) definition, heritage tourism is based on heritage, which is the central element of the product on the one hand, and the main motivation for tourists on the other. We can say, in general, that it is a type of tourism directed towards the acknowledgement of a destination's cultural heritage. According to Fladmark (1994), cultural heritage tourism means the identification, management and preservation of heritage, and, furthermore, helps to understand tourism's effects on local communities and regions, increases the economical and social benefits, and provides financial resources for preservation, marketing and promotion.

The other direction to our questions is the field of tourism innovations. No doubt, innovation is the motor of growth and competitiveness in the global world of tourism. We know from Schumpeter's (1934) typology that all five types can be found in tourism as well: (1) creation of new products or services, (2) new production processes, (3) new markets, (4) new suppliers and (5) changed organization or management systems. On the other hand, in practice, we can meet the lack of innovation in many parts of the tourism industry, mainly because it is dominated by small and medium size enterprises, or even private persons, who do not have their own research and development activities, like in bigger companies. Thus, cooperation is the only way to increase the competitiveness of the tourism industry.

Regarding tourism, the most well-known typology has been given by Weiermair, stating that the main points of tourism innovations are to give new target-tool combinations, new problem solutions-the possible forms are: (1) organic innovations (based on existing competences, relations and networks), (2) niche innovations (new, concentrated forms of existing competences), (3) organizational innovations (new cooperations without existing competences), and (4) revolutionary innovations (new competences on existing relations) (Weiermair, 2004; 2006):

As new product innovations can be easily and often adapted by others (though in cultural tourism, the uniqueness of heritage elements is a barrier in this), process innovations, quality improvements (resulting in the increase of uniqueness) and market-based innovations are becoming more and more essential. Innovations in tourism cannot be narrowed for individual innovative performances, but they are results of some kind of cooperation, where we can find the entrepreneurial level (stakeholders, employees, consumers, companies) and the community level (tourism offices, marketing agencies, national local and regional municipalities, clusters and destination management agencies) as well. The latter determine the economical, social, environmental, legal, organizational and other elements which influence the development of tourism, and, at the same time, serve as its environment. Their management has the greatest influence on the innovation process, which is very similar to the management of clusters. When regarding the experiment-centric feature of tourism we can accept that innovation is rather the result of a procedure than the output of the creativity of individuals.

Innovation in tourism is no longer a question of a giant leap forward-it is a series of small steps (evolution) that lead to incremental growth - it was one of the main statements of the Conference of OECD in 2003, in Lugano. 
We can approach innovations from several points of view: on market, destination or resource basis. In this study we do not wish to analyze the wide literature and models of tourism innovations. It is the resource-based, or competencebased approach which can be best applied to our case, i.e., cultural routes, where human, natural and cultural resources are all have to be utilized (Figure 1):

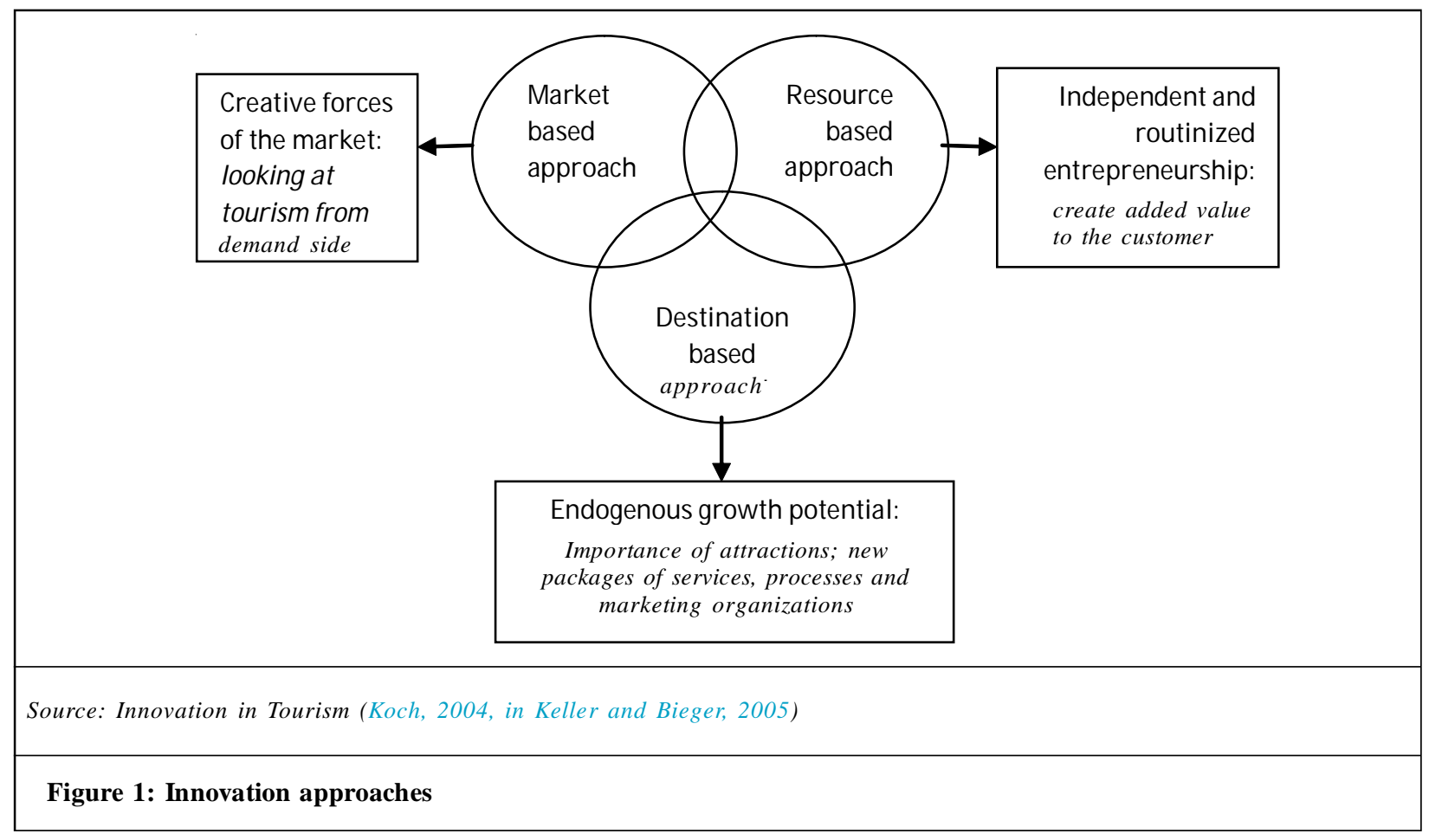

\section{Objectives}

The aim of our research is to study how different forms and models of cooperation, and the consequent joint marketing activities can effectively contribute to successful tourism innovations, product development and management, analyzing the examples of a specific field of tourism, i.e., cultural routes.

Cultural routes have a special, determining role among tourism products, especially those built on heritage elements. According to the general concept, cultural routes are such thematic roads where the central theme is some kind of cultural value, heritage element, and cultural attractions have dominant role (Dávid et al., 2007). On the contrary, our opinion is that it is necessary to emphasize a stronger borderline between the two concepts - thematic roads and cultural routes - and only the added value arising from heritage and culture can fulfill this expectation, and can serve as the basis for further requirements of development.

Cultural routes can provide possibility for visitors to understand and appreciate the given cultural relations. This intention has luckily met the tourists' demands for diversified products. Several countries and international organizations (e.g., UNWTO, UNESCO, ICOMOS, and EU) initiated such cooperations. "Route-based" tourism is a heritage and tourism development method serving not only tourism but also social and economical improvements. At the same time, a third concept also appears in literature, i.e., heritage trails, which have significant differences compared to cultural routes, as it is summarized in Table 1 (Chairatudomkul, 2008):

It is important to make these differences clear, because we will see in the third chapter that during the implementation of the project being presented, these meaningful differences have not been taken into consideration. Unfortunately, it is still quite common in Hungary....

Heritage-based cultural routes, compared to the traditional product development, have to meet several other social and community expectations as well. We have started from the four steps of successful cultural heritage tourism development, namely (1) access the potential, (2) planning and organizing, (3) preparing for visitors, preservation and management, and (4) marketing (www.culturalheritagetourism.org). We have analyzed the possible problems and means of solutions arising from complexity_occurring in the course of development and realization_and also the criteria of marketability and competitiveness. The success factors of heritage tourism projects are the following: (1) access and inclusion (access, inclusion, education, learning, ICT); (2) sustainability (regeneration, conservation, product renewal, financial resources, multiple uses, return visits); (3) catalysis (cooperation, value for money, return on investment, 
Table 1: Conceptual differences between cultural routes and heritage trails

\begin{tabular}{|c|c|c|}
\hline & Cultural routes & Heritage trails \\
\hline Characteristics & $\begin{array}{l}\text { Existing travelling routes functioned for religious, } \\
\text { commercial or military purposes through history. }\end{array}$ & $\begin{array}{l}\text { Created for tourism purposes, connecting nodal } \\
\text { attractions, in suitable distance and supported by } \\
\text { services. There are no necessary links to history. }\end{array}$ \\
\hline Networks & Cooperation in scientific research. & $\begin{array}{l}\text { Cooperation with tourism organizations for } \\
\text { promotion, without real scientific basis. }\end{array}$ \\
\hline Targets & $\begin{array}{l}\text { Cultural, economical and social aspects; fostering } \\
\text { interest and solidarity for heritage of other people } \\
\text { and communities. }\end{array}$ & $\begin{array}{l}\text { Economical benefits and tourism effects; social, } \\
\text { community and cultural benefits are secondary. }\end{array}$ \\
\hline Authenticity & $\begin{array}{l}\text { Collection of heritage items, which were directly } \\
\text { connected through history, for a continuous cultural } \\
\text { exchange. }\end{array}$ & $\begin{array}{l}\text { There are no heritage items resulting from cultural } \\
\text { exchanges over quite a long period in history. }\end{array}$ \\
\hline Importance & $\begin{array}{l}\text { Important considering relations and influences } \\
\text { between two or more cultural communities (groups). } \\
\text { Common roots are determining in understanding of } \\
\text { cultural heritage. }\end{array}$ & $\begin{array}{l}\text { Experiences and enjoyment are in focus - visitors } \\
\text { can increase the sense of local proudness. }\end{array}$ \\
\hline
\end{tabular}

structured and multiple agendas); and (4) competitiveness (quality and standards, benchmarking, marketing, management, visitor satisfaction) (Nurick, 2000). All these elements have to be built into the proper phases of tourism product development, too.

\section{Methodology}

Regarding the 7Ps of individual tourism marketing and the $2 \mathrm{Cs}$ of community marketing, we consider cooperation to be one of the most important endogenous attribute. Our starting hypothesis is that the more complex a tourism product is, the more broader and well-planned cooperation, that is the so-called stakeholder-management is necessary between the enterprises and community (non-profit) tourism organizations (Ruckh et al., 2006).

We have carried out our first research during and after a project aiming to develop joint tourism packages on thematic routes, in the framework of the Hungary-Slovakia Cross-border Cooperation Program 2007-2013. We have used mainly quantitative methods, structured questionnaire survey among tourism enterprises, organizations, and tourism and marketing experts, plus interviews. We have examined the cooperational abilities and intensity of the tourism actors of both countries, exploring significant differences regarding both objectives of cooperation and groups of those concerned.

We have found that $65 \%$ of the Hungarian and $40 \%$ of the Slovakian tourism enterprises have some kind of existing partnerships. Concerning future cooperations, the first four most important organizations are, in case of Hungarians, tourism information centers (91\%), regional tourism marketing organizations (70\%), accommodations (65\%) and restaurants (61\%). In case of Slovakians, tourism civil organizations (70\%), travel agencies (70\%), tourism information centers (50\%) and regional tourism marketing organizations (50\%) reached the first positions (Figure 2).

We have asked the experts about the importance of the same elements. As the number of the participants of the survey has been much less than in the previous case, we have ranked the elements. The most important ones, in a 5point scale, are the following: (1) attractions fitting into the route [it is quite evident], (2) other spare-time possibilities, (3) tour operators, (4) destination management agencies, (5) tourism information centers, plus travel agencies, accommodations and restaurants with the same importance (Figure 3).

The results have made it clear that there are essential shortcomings in the tourism entrepreneurs' cooperational and product development knowledge, especially in comparison with the experts of the theme. Our entrepreneurs are now "learning" that—besides the individual, mainly material interests—community interests and organizational relations are 


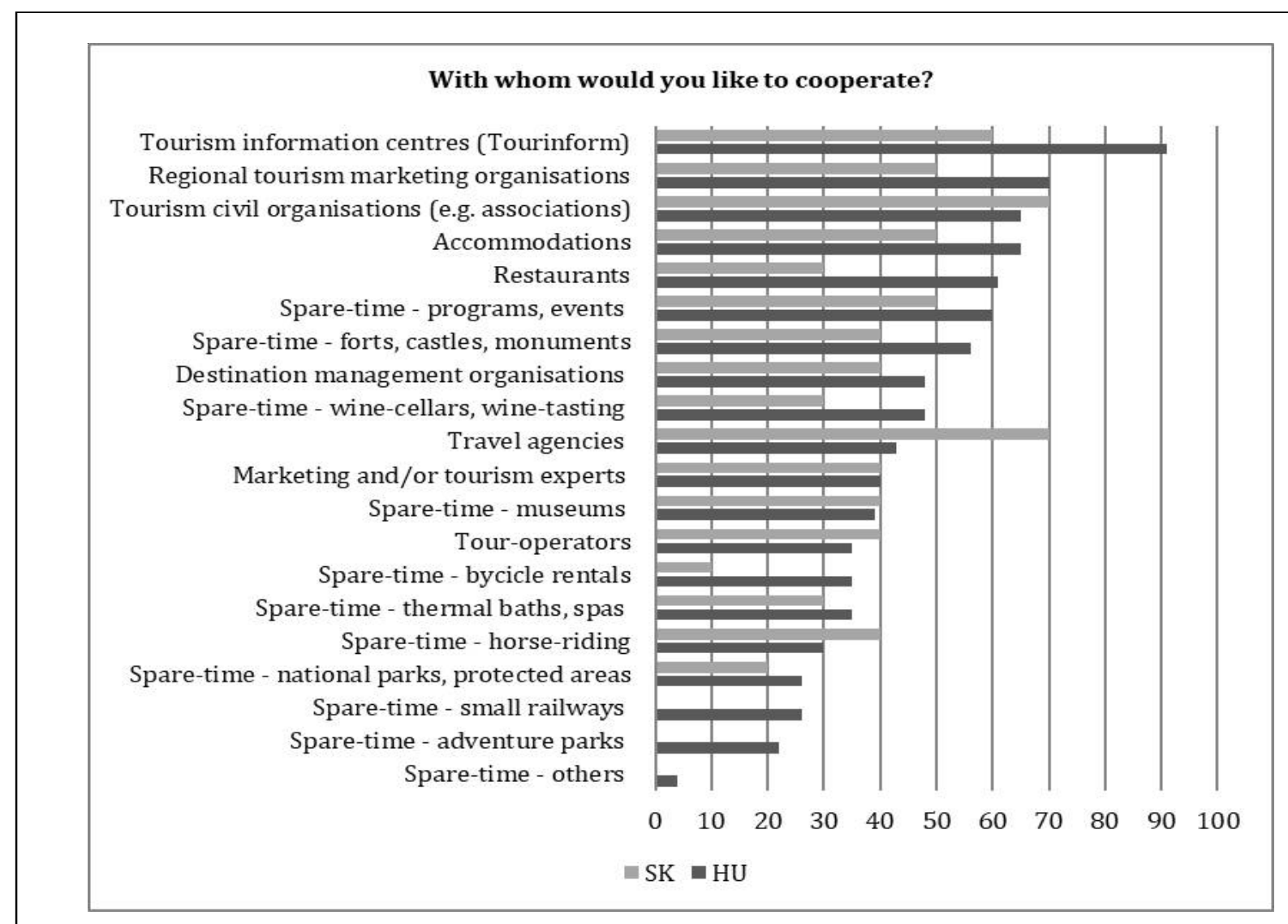

Figure 2: Cooperation partners according to importance, entrepreneurial survey, arranged by Hungarian answers

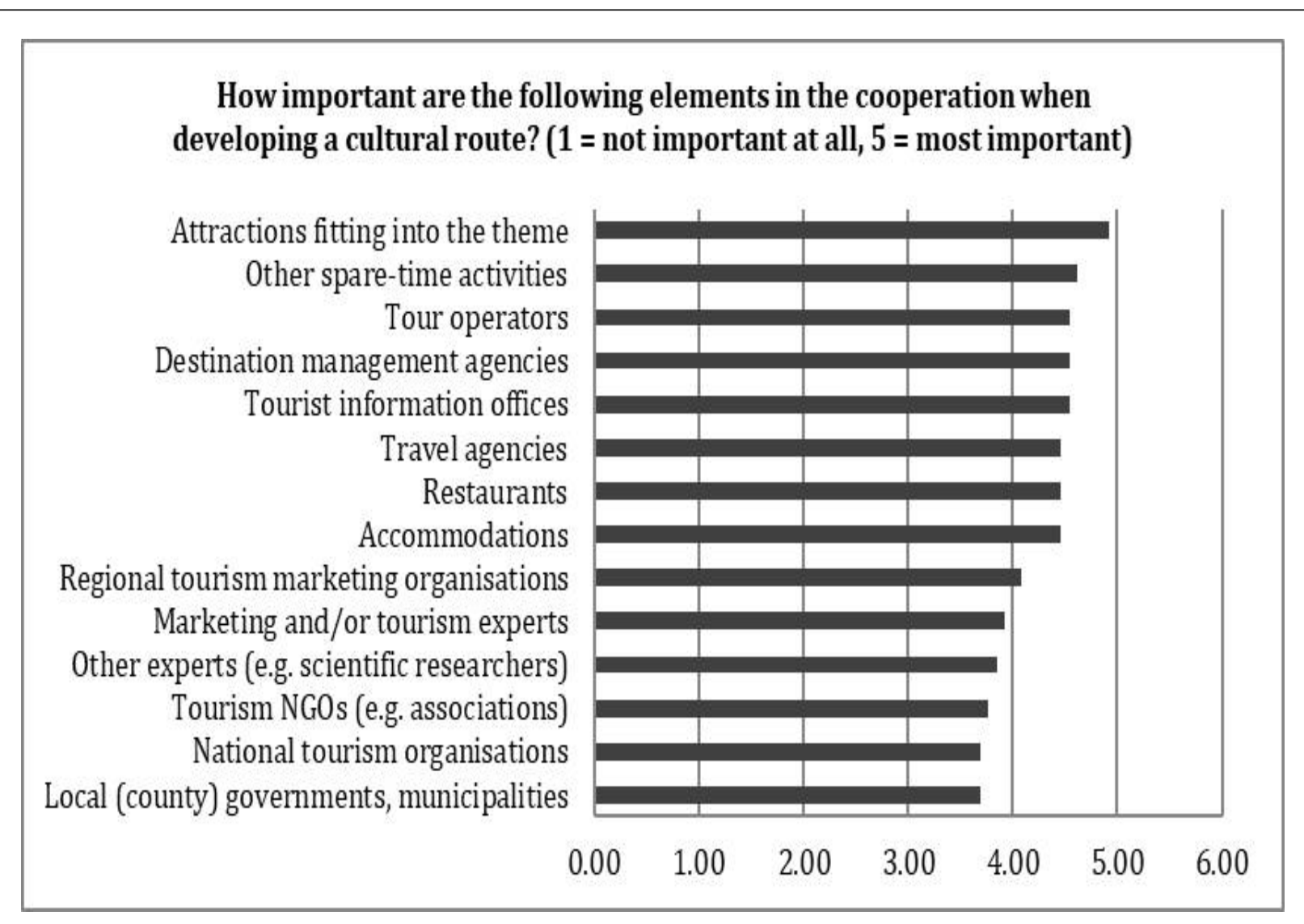

Figure 3: Ranking of cooperation partners, expert survey 
also important. They consider new product development as the main tool in renewal; they understand the importance of marketing and rely more and more on organizations carrying out community marketing activities—but, at the same time, sale does not seem to be such determinant (see the relatively low position of tour operators and travel agencies). The cooperations are not conscious, rather spontaneous, built on a given opportunity. This is the reflection of the fact that there are no traditions of destination management agencies-in Hungary, their establishment has started only in the past 3-4 years, the process is quite difficult, pressed mainly by the municipalities, and the engagement of entrepreneurs is slow. In Slovakia, this process is even slower, the system is dominated either by clearly non-profit or business organizations.

It is reflected in the experts' answers that product formation has to focus on complexity, both individual and social marketing, individual and community interests are equally important in cooperation, they can contribute to competitiveness by strengthening each other. However, the fact that cultural routes are much more than simply thematic routes is not emphasized properly; scientific background and the participation of experts can substantiate successful operation and long-term quality guarantees. In so far as we possess theoretical knowledge, its practical translation and attitude formation of entrepreneurs in practice cannot be considered effectual.

Concerning cooperation targets, Hungarians considered the following element the most important: reaching new guests $(74 \%)$, new promotion channels $(60 \%)$ and more successful low seasons $(56 \%)$. Slovakians ranked new promotion channels (90\%), more successful low seasons (80\%), reaching new guests and obtaining professional information (70\%) in the first three places (Figure 4). Similarly like in the previous case, we have ranked these factors by the expert survey, and the first positions are occupied by the following elements: reaching new guests, enlargement of existing markets, reaching new markets, better market positions, and more successful low seasons, reduction of the effects of seasonality (Figure 5). Economical factors (like e.g., reduction of costs), or professional issues (like marketing and cooperation) have significantly lower assessment.

The correspondence to the international trends of competitiveness and complexity is reflected again in the experts' answers, while the opinion of the experiential actors of tourism is dominated by individual, direct market efforts and market interests. However, the Slovakian entrepreneurs' demand for professional information, knowledge and knowhow is surprisingly outstanding, forecasting another path for development being different from the Hungarian one.

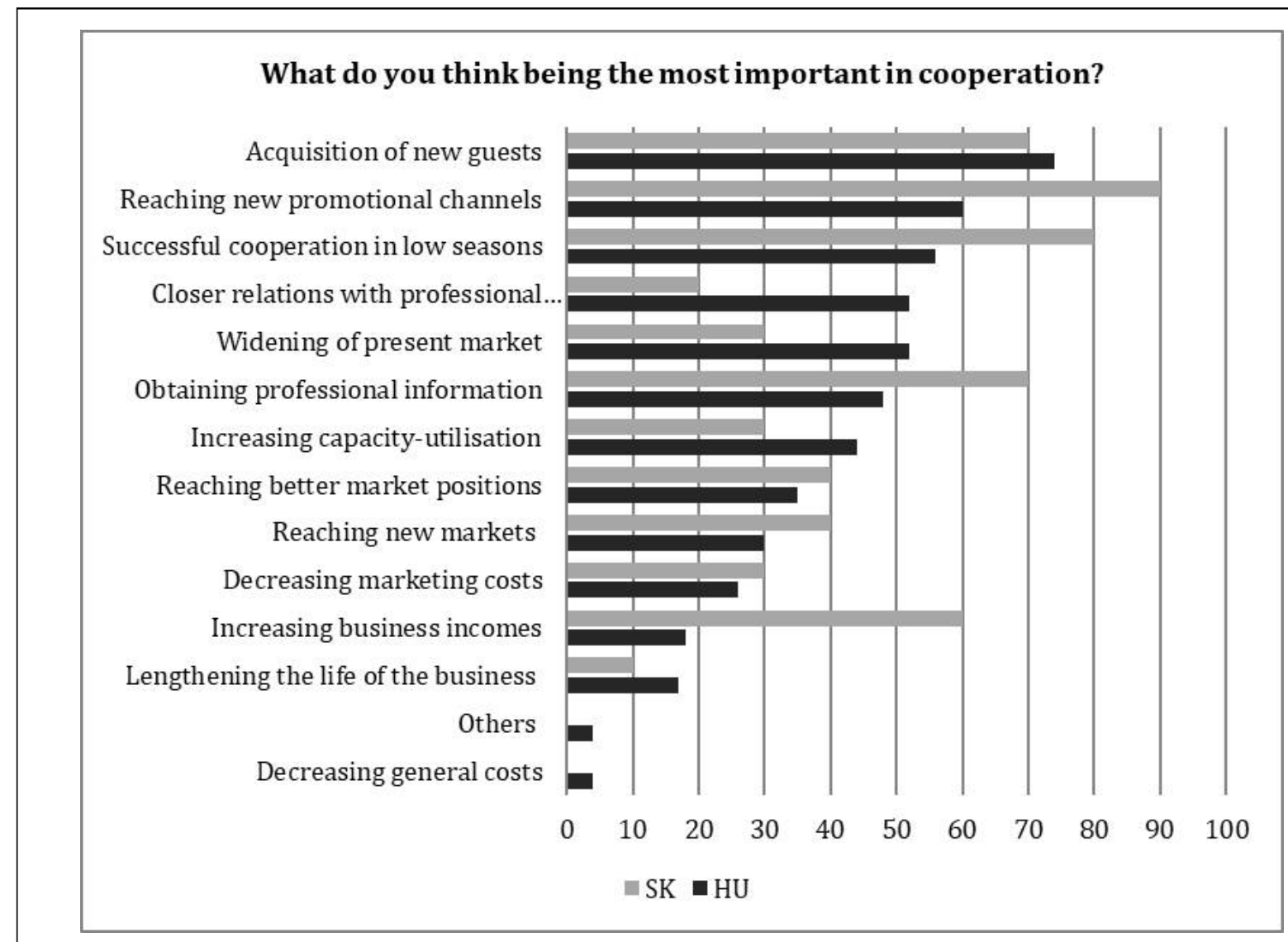

Figure 4: Main targets of cooperation, entrepreneurial survey, arranged by the Hungarian answers 


\section{What do you think being the most important in a cooperation? Please, rank the following elements!(1=most important, then go on)}

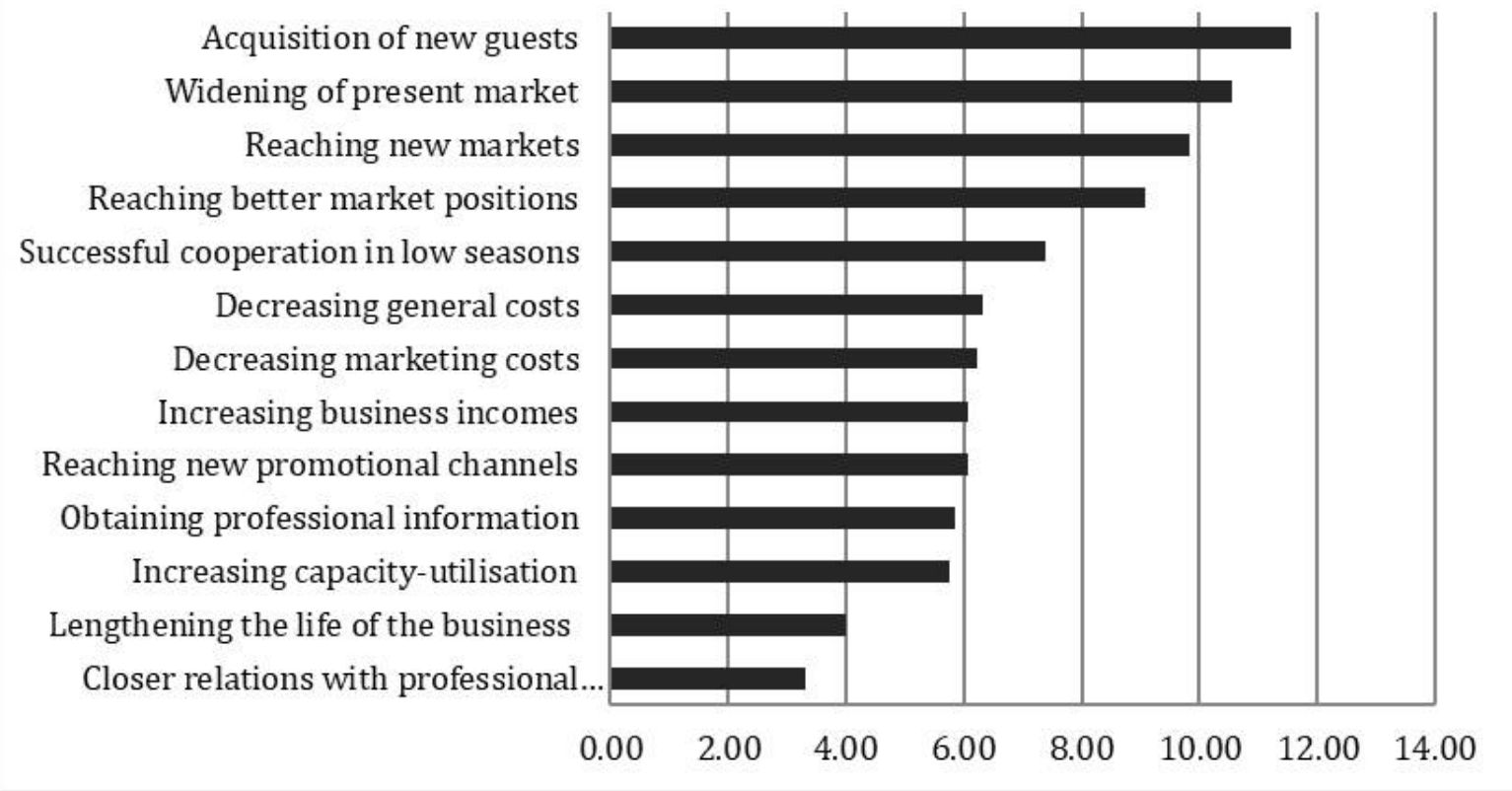

Figure 5: Ranking of the targets of cooperation, expert survey

The results of our research have supported that, in spite of the striking differences in behavior and attitudesarising from the different levels of tourism organizations and management in the two countries-organizational cooperations get considerable emphasis in tourism product development and management. Solutions mixing business and social marketing techniques equally appeared in the development and management of cultural routes as complex tourism products, but, at the same time, they have not formed an efficient cooperational system. International theories and models could have not been successfully adapted, the intentions have stayed on the level of elaborating new offers, and only entrepreneurs have been addressed; the aspects of community interests, building on adequate background and complexity have been under-valued and left out of consideration. As a consequence, the new products (offers) have not been introduced to the market, the questions of organized sale were not solved, and there is still not a responsible organization, thus quality control and monitoring is still lacking. On the basis of our analyses and results we can find that significant cooperational and coordination deficit hinders the successful establishment and operation of cultural routes. At the same time, significant improvement can be reached by applying the planning and organizational solutions, combined tools of social marketing — as through the complexity and value-principled feature of these products, regarding the societal task of the management of heritage, the analogy is obvious. Our related researches have displayed that the solution is in the integrated strategic approach, which is the cooperation of the different involved actors, entrepreneurs, municipalities, professional and civil organizations. We have to solve the tasks of stakeholder management based on the establishment of a peculiar value-community, and integrated marketing combining certain competences.

\section{Case study}

Here we present - with regard to the above results - a successful example, the system of the Cultural Routes of Switzerland, and draw a parallel with a similar Hungarian cultural route initiation, where the tools and methods of social marketing could be of great help.

In Switzerland, during the great infrastructure development programs of the 1970s it was discovered that the old traditional, mainly pilgrimage, commercial and military roads may completely disappear. Thus, acknowledging the value and its importance, the federal state asked an interdisciplinary expert team of the University of Bern to map these old roads. The Inventory of Historical Traffic Routes in Switzerland (IVS) has been compiled between 1984-2003, after 20 years work of 30 persons, with 50 million CHF (Swiss Frank) federal investments, containing detailed maps, descriptions, historical and scientific information. The inventory rests upon Article 5 of the Swiss Federal Law for the Protection of 
Nature and Cultural Heritage. After the work has been completed, a national - regional - local classification has been set up. Originally, IVS has been created as a planning tool. At the same time, even during the production of the IVS it became obvious that historic routes with their attractive features, natural environment and cultural sights, have a great potential for both tourism and regional development. This is how the project Cultural Routes of Switzerland has been started ...

After finishing the inventory in 2003, the expert team stayed together and established the organization named ViaStoria, with the purpose of preserving the considerable amount of specialized knowledge and continuing to work on the exploration, renovation and appropriate use of historic traffic routes. The Cultural Routes of Switzerland project has three main goals:

- offering a new holiday experience, carefree hiking along historic routes,

- Using the academic research results (IVS) as a basis for new tourist packages, and

- Linking regional and local tourism initiatives with providers of local agricultural production and helping to create more added values in the regions.

The program is based on the network of 12 via routes. Each of them represents a special part of the Swiss culture and history. The inclusion of agriculture and handicrafts can further emphasize the historical traditions and commercial past of the certain regions.

However, the project has not been finished at this point. The experts have chosen 300 more routes of local and regional importance, and the tasks of tourism product and offer formation is still going on. Thus the cooperation between national and cantonal level will enhance, and a complex national network will be established. It is really important to emphasize that each route has its own responsible organization, the coordinator and manager of the local/ regional initiatives, carrying out the operation of the tourism offer. It is also possible to book packages in case of all 12 national routes. As the cultural routes of Switzerland program has been established, ViaStoria functions as an umbrella marketing organization, and became responsible for maintaining the national information platform, producing publications, ensuring a uniformity of quality and marketing the products at a national level. Research, counseling and information are the three most important domains of their activity, and they have elaborated a special program, a "tool-kit" with nature preservation (cultural landscape), agriculture (regional products), tourism and education (didactics) sections.

Industrial heritage appears in the offer of cultural and heritage tourism and it is part of the cultural routes of the European Council. The Iron Route of Central Europe has been established in 2007 with the following participating countries: Austria, Czech Republic, Germany, Hungary, Italy, Poland, Slovakia and Slovenia. Centuries ago, Hungary has been known as the "iron heart" of Europe, with deep roots of metallurgic and iron manufacturing traditions. Northern Hungary was the flagship of great industries before the political transformation, mainly by mining and metallurgy. By today, the two largest ironworks in Miskolc and Ózd ceased to produce, the factories have been closed several years ago, the ownership structure is disintegrated, and the real utilization of these huge areas is unsolved. Almost 20 years ago, some enthusiastic, committed specialists, mainly older representatives of the metalworker profession, have started a "never-ended" work trying to reveal, preserve and present the industrial heritage. The Central European Industrial Heritage Route Association has been established in 2008 with its seat in Miskolc. Their main targets are to reveal and preserve the industrial heritage; to safeguard the traditions; to replace production (even just partly) and the proper utilization of the huge brown field territories.

They had several success and failures in the last years. A few new industrial exhibitions could be established; the existing museums could be kept; and with the help of some marketing activities (publications, programs, scientific forums and iron factory tours occasionally) they could call the attention to these values. On the other hand, naturally we know that tourism alone cannot be the solution for such huge industrial areas, in spite of the several good examples of, for instance, the Ruhr region or Austria, in spite of examining the best practices. Principally they have to be the scenes of production, economical activities - with wisely planned and integrated tourism possibilities. Referring back to the project we have presented in the previous chapter, one of the joint Hungarian-Slovakian product formations was along industrial heritage, too, based mainly on the traditions of the common history. Then, what is the reason for the fact that this product cannot be function as a cultural route in Hungary?

The historical background similarly exists, like in Switzerland. But there are great deficiencies in almost all other factors (Figure 6). There is not a complete inventory; only partially, an assessment of the existing objects and places has been evaluated within the project, of those which could be utilized in tourism. There is not any conception or strategy for the management and utilization of these industrial landscapes and areas. Although scientists and civil organizations are aware of the problems, there is no responsible management organization-even in the sub-field of tourism, not to 
mention other economical and social problems. The dialogue with the local destination management agency (which is now under formation) is loose and casual. There are no financial resources for either product development or marketing tasks. A wide social dialogue has been started recently, going on at the same time of our present study, but the solutions still seem to be far away. In fact, regarding industrial heritage, we have wasted the last two decades... A real, complex program would be necessary together with the establishment of a realizing management organization and cooperation system.

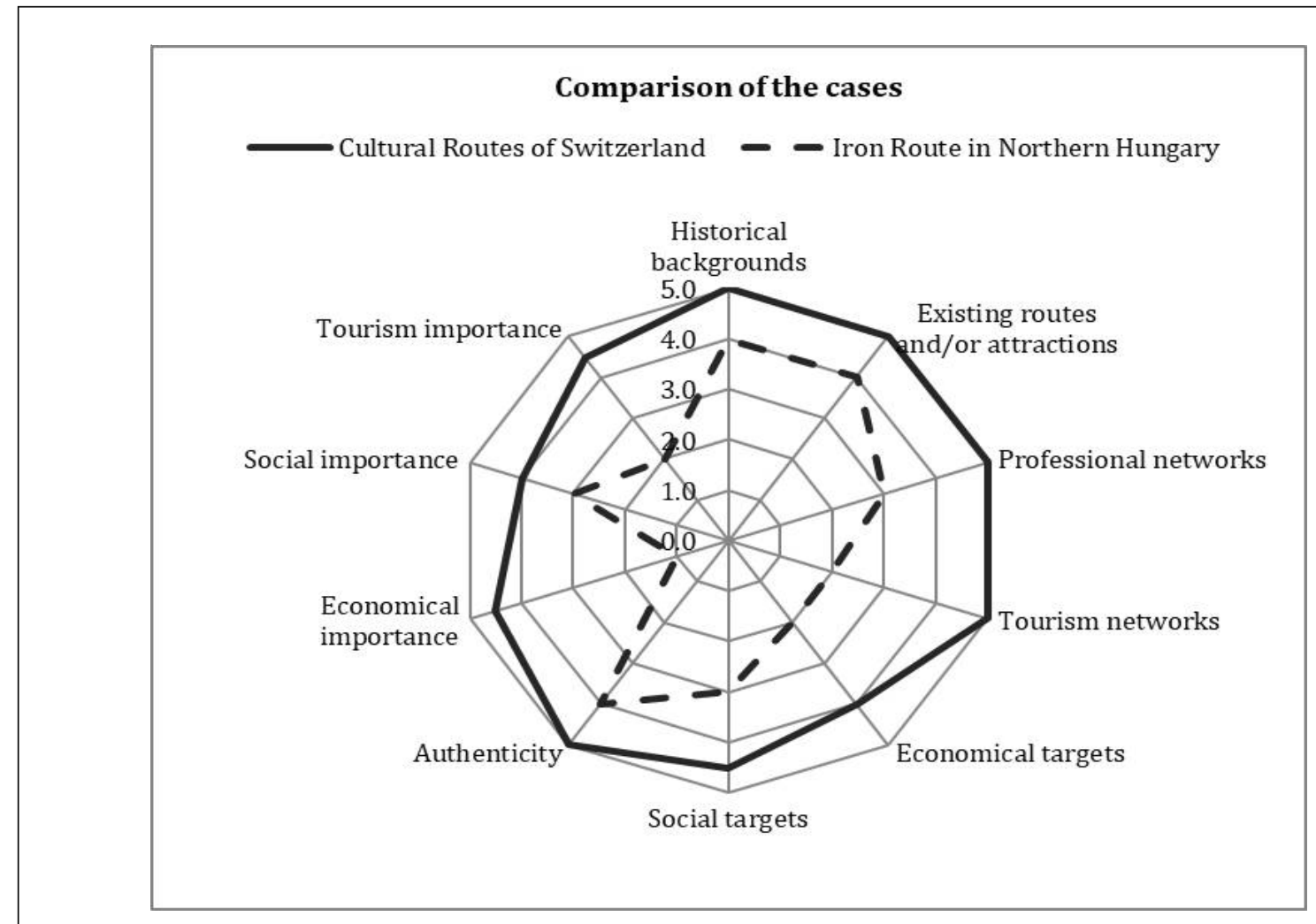

Figure 6: Comparison of the case studies

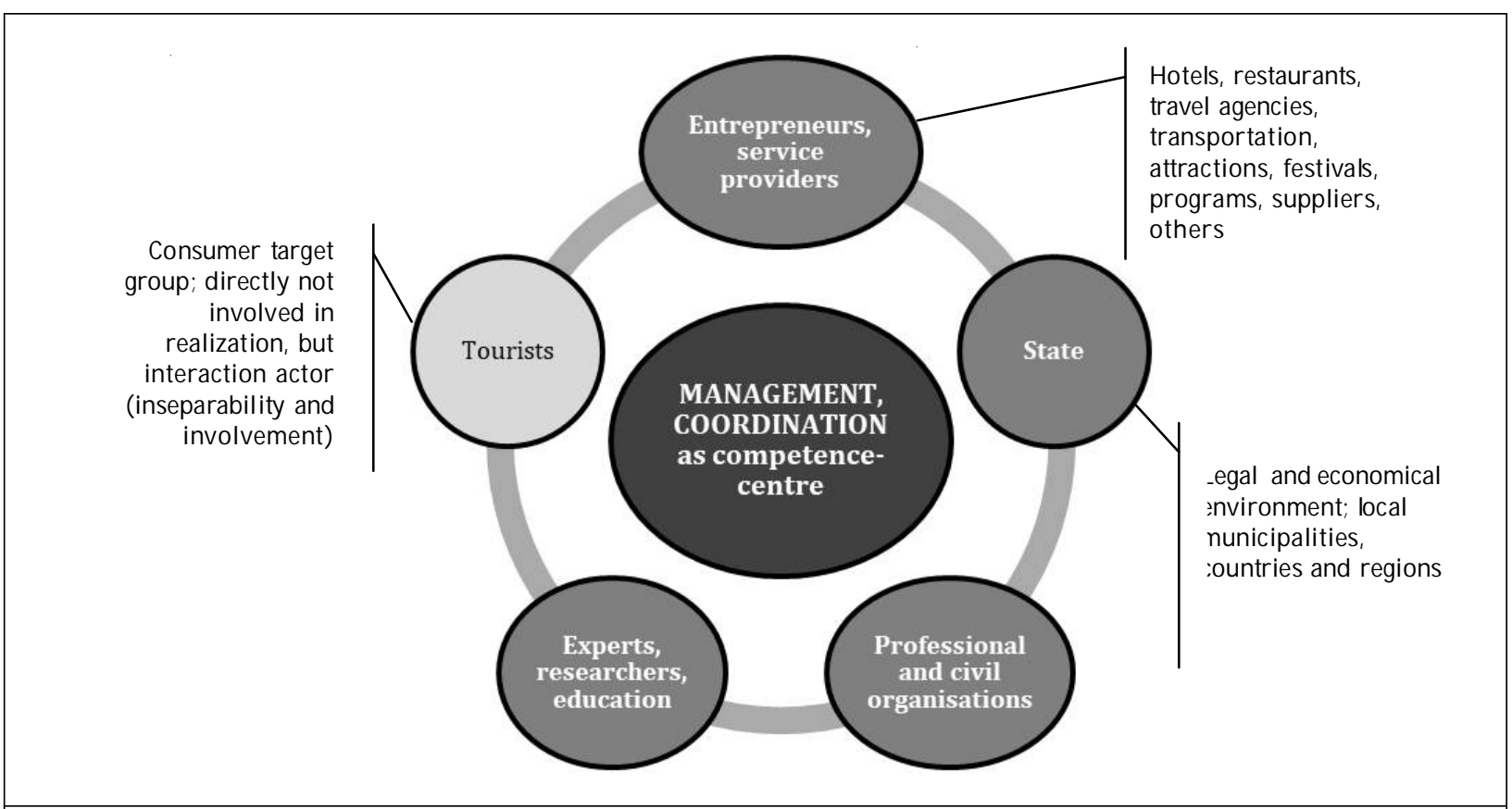

Figure 7: Cooperation model for cultural routes 


\section{Conclusion}

Our tested cooperational model (Figure 7), which is formed on the basis of competence-marketing, introduces the determining actors of heritage-based cultural routes, their importance and roles, emphasizing the importance of the existence of an adequate coordinating-managing marketing organization. According to our results, the absence of such an organization hinders the successful operation of cultural routes, which was confirmed by the comparison of the examples of the case study.

The integrating competence center, which can be interpreted as a special cluster organization, is responsible for the conscious internal (building the captivation and cooperation of the actors) and the outside, tourism market centered, community-based marketing activities. The basic condition of competitive establishment and operation of cultural routes is the strengthening of the present weak cooperation abilities and skills, with the help of methods and tools of the social marketing model.

\section{Acknowledgment}

This paper and the conference participation are carried out as part of the TAMOP-4.2.2/B-10/1-2010-0008 project in the framework of the New Hungarian Development Plan. The realization of this project is supported by the European Union, cofinanced by the European Social Fund.

\section{References}

Chairatudomkul, S. (2008). Cultural routes as heritage in thailand: case studies of king narai's royal procession route and buddha's footprint pilgrimage route (PhD Thesis). Silpakorn University, Bangkok, Thailand.

Dávid, L., Jancsik, A. and Rátz, T. (2007). Turisztikai erõforrások-a természeti és kulturális erõforrások turisztikai hasznosítása, Perfekt Kiadó, Budapest.

Fladmark, J.M. (1994). Cultural tourism: papers presented at the Robert Gordon University Heritage Convention, Conference proceedings book. Donhead Publishing, London.

Four Steps for Successful Cultural Heritage Tourism. Cultural Heritage Tourism website [www.culturalheritage tourism.org]. Available at: http://www.culturalheritagetourism.org/fourSteps.htm [Access date 19.09.2012]

Gyöngyösy, Z. and Lissák, Gy. (2003). Termékpolitika, terméktervezés, termékdesign, Miskolci Egyetemi Kiadó, Miskolc.

Hall, C.M. and McArthur, S. (1998). Integrated Heritage Management. Principles and Practice. The Stationery Office, London, UK.

Keller, P. and Bieger, T. (2005). Innovation in Tourism - Creating Customer Value, Editions AIEST, St. Gallen, Switzerland.

Lagrosen, S. (2005). Customer involvement in new product development. A relationship marketing perspective. European Journal of Innovation Management. 8(4), 424-436.

Lengyel, M. (2004). A turizmus általános elmélete, Heller Farkas Fõiskola, Budapest.

Levitt, T. (1981). Marketing intangible products and product intangibles. Harvard Business Review. May-June, 37-44.

Martorell, A.C. (2003). Cultural routes: Tangible and intangible dimensions of cultural heritage. ICOMOS [www.icomos.org] Available at: http://www.international.icomos.org/victoriafalls2003/papers/A1-5\%20-\%20Martorell.pdf [Access date 24.02.2013] (In: 14th ICOMOS General Assembly and International Symposium: 'Place, memory, meaning: preserving intangible values in monuments and sites', 27 - 31 Oct 2003, Victoria Falls, Zimbabwe).

Medlik, S. and Middleton, V.T.C. (1973). Product formulation in tourism. Tourism and Marketing. Vol.13. Berne, AIEST.

Michalkó, G. (2012). Turizmológia, Akadémiai Kiadó, Budapest.

Middleton, V.T.C. and Clarke, J. (2001). Marketing in Travel and Tourism.124-125, $3^{\text {rd }}$ Edition, Butterworth-Heinemann, Oxford.

Nurick, J. (2000). Heritage and tourism, Locum Destination Review. (2), 35-38.

Nuryanti, W. (1996). Heritage and postmodern tourism. Annals of Tourism Research. 23(2), 249-260.

Puczkó, L. and Rácz, T. (2000, 2011). Az attrakciótól az élményig, Geomédia Kiadó, Budapest; and Akadémiai Kiadó, Budapest.

Richards, G. (2003). What is cultural tourism? In van Maaren, A. (ed.) Erfgoed voor Toerisme. Nationaal Contact Monumenten. 
Ruckh, M., Noll, Ch. and Bornholdt, M. (Hrsg.). Sozialmarketing als stakeholder-management. Bern-Stuttgart-Wien, 2006, Haupt Verlag, 343.

Schumpeter, J.A. (1934). The Theory of Economic Development, NY, Oxford University Press.

Silberberg, T. (1995). Cultural tourism and business opportunities for museums and heritage sites. Tourism Management. 16(5), 361-365.

Smith, S.L.J. (1994). The tourism product, Annals of Tourism Research. 21(3). 582-595, Elsevier Science Ltd. USA.

Swarbrooke, J. (1994). The future of the past: heritage tourism into the 21st century. In: Seaton, A.V. (ed): Tourism. The Stateof the Art. John Wiley \& Sons, Chichester, 222-229.

Tunbridge, J.E. and Ashworth, G.J. (1996). Dissonant Heritage: The Management of the Past as a Resource in Conflict. John Wiley \& Sons, Chichester.

Weiermair, K. (2004). Product improvement or innovation: What is the key to success in tourism? OECD [www.oecd.org] available at www.oecd.org/dataoecd/55/31/34267947.pdf [Access date 23.01.2013].

Weiermair, K. (2006). Prospects for innovation in tourism, Journal of Quality Assurance in Hospitality \& Tourism. 6(3-4), 59-72.

Cite this article as: Piskóti, István and Nagy, Katalin (2021). Individual and social marketing in cultural routes operation. International Journal of Tourism and Hospitality. 1(1), 14-24. doi: 10.51483/IJTH.1.1.2021.14-24. 